\title{
The Black-Scholes Currency Option Pricing Model: Evidence for Unbiasedness from Three Currencies against the US Dollar
}

\author{
Samih Antoine Azar $^{1} \&$ Annie Tortian ${ }^{1}$ \\ ${ }^{1}$ Faculty of Business Administration \& Economics, Haigazian University, Beirut, Lebanon \\ Correspondence: Samih Antoine Azar, Professor, Faculty of Business Administration \& Economics, Haigazian \\ University, Mexique Street, Kantari, Beirut, Lebanon. Tel: 961-134-9230. E-mail: samih.azar@haigazian.edu.lb
}

Received: May 29, 2013

Accepted: June 8, $2013 \quad$ Online Published: July 26, 2013

doi:10.5539/ijef.v5n8p54

URL: http://dx.doi.org/10.5539/ijef.v5n8p54

\begin{abstract}
Under risk neutrality and rational expectations, the future value of the option premium is an unbiased estimator of the future actual payoff of the option. In this paper, this unbiasedness hypothesis is tested for the Black-Scholes currency call option pricing model. Three currencies, against the US dollar, are considered: the British pound, the Swiss franc, and the Japanese yen. The data is monthly and starts from the late 1980s. A set of seven different strike prices are assumed for each currency. Unbiasedness is supported if the regression constants are statistically insignificant, and if the regression slopes are statistically insignificantly different from 1 , and if there is no autocorrelation in the regression residuals. The results for the British pound are strongly supportive of this version of market option efficiency. For the other two currencies only long run cointegration relations are uncovered. The results, whether short run or long run, remain also strongly supportive when the theoretical constraints are imposed. In addition, the results are not materially different with alternative measures of currency volatility. It can be concluded that the Black-Scholes currency option pricing model is relevant not only theoretically but also empirically and practically.
\end{abstract}

Keywords: Black-Scholes currency option pricing model, British pound, Swiss franc, Japanese yen, European currency call options, rational expectations, unbiasedness, market efficiency

\section{Introduction}

The unbiasedness hypothesis states that the current forward rate is an unbiased predictor of the future spot rate. Unbiasedness is ordinarily tested in the foreign exchange market, although nothing prevents its application to other markets. Unbiasedness of the forward foreign exchange rate is sometimes called forward market efficiency. This paper has the purpose to test whether unbiasedness holds for Black-Scholes currency option prices. This test is crucial to the Black-Scholes option pricing model, and is intended to determine whether this model remains appropriate and useful despite the fact that it has been discovered to have many biases when applied to foreign exchange rates (Chesney and Scott, 1989; Dupoyet, 2006; Hull, 2012). See also Reiswich and Wystup (2010) who deal with the issue of volatility smiles in currency options, whereby implied volatility from option prices varies with the degree of moneyness. This paper introduces in the second section an original experimental design to test for option unbiasedness, or what may be called henceforth option market efficiency. This concept of efficiency is not the same as the ones in the literature where efficiency is defined either as the unbiasedness of implied volatility in predicting actual volatility (Shastri and Tandon, 1986) or whether option prices satisfy the no-arbitrage put-call parity condition (Hoque et al., 2008).

A related but a different approach to this paper's option unbiasedness model is the one adopted by Duan and Simonato (1998), Harikumar et al. (2004), and Shahbandarzadeh et al. (2013). These authors consider the following approximate call option pricing model for a call option premium $\left(C_{t}\right)$ on a non-dividend-paying stock at time $t$, where $r$ is the domestic interest rate, $T$ is the maturity, $S$ is the stock price, $K$ is the strike price, $E()$ is the expectation operator, and $n$ is the number of simulations:

$$
C_{t}=e^{-r T} E\left[\operatorname{Max}\left(S_{T}-K, 0\right)\right] \approx e^{-r T} \operatorname{Max}\left[E\left(S_{T}\right)-K, 0\right]=\frac{1}{n} e^{-r T} \sum_{i}^{n}\left(\operatorname{Max}\left[S_{i T}-K, 0\right]\right)
$$

The approximation in equation (1) holds better if Jensen's inequality is small, as is usually the case, although Azar (2008) finds that Jensen's inequality is statistically significant in many applications in finance. In support 
indirectly to Azar (2008) Harikumar et al. (2004) obtain evidence that the Black-Scholes pricing model generates more accurate prices than a more sophisticated GARCH model of currency returns that uses equation (1), implying implicitly that Jensen's inequality cannot be ignored. This reestablishes the relevance and appropriateness of the Black-Scholes pricing model despite its many critics. The evidence in this paper further demonstrates the salient features of relevance and appropriateness of such a model.

The paper is organized as follows. In the following section, section 2 , the experimental design is presented. The empirical results are in section 3. Section 4, the final section, concludes.

\section{The Experimental Design}

As already stated in equation (1), and in a risk-neutral world, the following is true (Hull, 2012, p. 314):

$$
C=e^{-r T} E\left(\operatorname{Max}\left[S_{T}-K, 0\right]\right) \text { or } e^{r T} C=E\left(\operatorname{Max}\left[S_{T}-K, 0\right]\right)
$$

If rational expectations are invoked, then:

$$
\operatorname{Max}\left[S_{T}-K, 0\right]=E\left(\operatorname{Max}\left[S_{T}-K, 0\right]\right)+\varepsilon_{T}
$$

where $\varepsilon$ is the expectation error. Replacing equation (2) into equation (3) one obtains:

$$
\operatorname{Max}\left[S_{T}-K, 0\right]=e^{r T} C+\varepsilon_{T}
$$

The RHS result of Equation (4) has the form of a simple linear regression where the slope is equal to +1 , and the constant is equal to 0 . The paper will assess whether these two constraints are going to hold. Moreover, for short run and long run unbiasedness to be verified the residual $\varepsilon_{T}$ should not be autocorrelated, meaning that the residual should be orthogonal to past information and that all relevant information about the option actual payoff should already be incorporated in the future value of the option premium. For long run unbiasedness to hold, which is a weaker condition of unbiasedness, the two variables in equation (4) should be cointegrated.

The presence of autocorrelation, or serial dependence, is evaluated by the Ljung-Box (1978) Q-statistic at lag k:

$$
Q(k)=N(N+2) \sum_{i=1}^{k} \frac{\rho_{i}^{2}}{(N-i)}
$$

where $N$ is the sample size, and $\rho_{i}$ is the autocorrelation coefficient at lag $i$. This Q-statistic is distributed as $\chi^{2}$ with $\mathrm{k}$ degrees of freedom under the null hypothesis of no autocorrelation. Three lag lengths (k) are used: 6 , 12 , and 24. In case of cointegration the residual in equation (4) may be autocorrelated but should however be stationary in distribution.

It must be noted that the unbiasedness hypothesis is not invalidated by non-linear dependence, or heteroscedasticity, i.e. when the residuals in the time series regressions are not identically distributed. As a matter of fact all the estimated regressions in this paper suffer from some type of heteroscedasticity. That is why heteroscedastic and autocorrelation robust standard errors and covariances (HAC) are applied using the Newey and West (1987) correction.

The first currency to be studied is the British pound against the US dollar. It is expressed with the American convention against the US dollar, i.e. in terms of US dollars per unit of British pound. This is in conformity to actual quotes in the markets for spot rates, futures and for options, and in conformity to the common usage in the academic literature. The other two foreign currencies are converted in terms of US dollars per one unit of foreign currency, which is the opposite of the actual quotes in foreign exchange markets. The data on end-month exchange rates and on end-month one-month LIBOR rates are retrieved from the web page of EconStats. The sample is monthly from 1987:1 to 2012:10 for the British pound, i.e. 310 observations, and from 1989:1 to 2012:10 for the other two currencies, i.e. 286 observations. Missing values for LIBOR rates are taken from the following website: www.global-rates.com. Call premiums are computed according to the Black-Scholes (1973) and Merton (1973) option valuation formulae, as modified by Garman and Kohlhagen (1983), Grabbe (1983), and Biger and Hull (1983):

$$
\text { call premium at time } t=C_{t}=e^{-r f T} S_{t} \phi\left(d_{1}\right)-e^{-r T} K \phi\left(d_{2}\right)
$$


where $\phi($.$) is the standard cumulative normal distribution, S_{t}$ is the spot price of the foreign currency, $K$ is the strike price, $r$ is the domestic interest rate, $r f$ is the foreign interest rate, $T$ is the term, and where:

$$
d_{1}=\frac{\log \left(S_{t} / K\right)+\left(r-r f+0.5 \sigma^{2}\right) T}{\sigma \sqrt{T}} \text { and } d_{2}=d_{1}-\sigma \sqrt{T}
$$

The term $T$ is fixed as being one month. The volatilities $(\sigma)$ are either retrieved from the conditional variance through GARCH methods or assumed to be constant. See Engle (1982) for the ARCH model and Bollerslev (1986) for the GARCH model. More than one strike price is assumed. In fact there are seven strike prices for each currency. For the British pound these are in US dollars: 1.50, 1.55, 1.60, 1.65, 1.70, 1.75, and 1.80. For the Swiss franc they are in US dollars: $0.65,0.70,0.75,0.80,0.85,0.90$, and 0.95 . For the Japanese yen these are in US cents: $0.70,0.75,0.80,0.85,0.90,0.95$, and 1.00 . For each strike price the actual payoffs are computed. Then the monthly Black-Scholes option prices are computed with variable domestic and foreign interest rates and variable spot foreign exchange rates over the sample period. The actual payoffs are regressed onto the future value of the Black-Scholes option values as specified by equation (4).

\section{The Empirical Results}

While the actual call option payoffs are easily calculated, the Black-Scholes call premiums require an estimate of the volatility of the underlying asset, in addition to spot foreign rates, and to domestic and foreign interest rates. Two methods are adopted. One is to estimate the volatility according to GARCH models of the change in the logs of each currency (Table 1). See also Manzur et al. (2010) and Dash et al. (2012). The change in the logs is approximately equal to the percentage change, especially with high-frequency data like this paper's monthly data The GARCH specification models the residual variance as time-dependent or time-variable, and can account for volatility clustering, which is a stylized feature of many assets, and not only of foreign exchange rates, although some authors did not find GARCH effects in monthly foreign exchange rates (Baillie and Bollerslev, 1989). The other method is by assuming a constant volatility. The first method finds significant GARCH effects for all three currencies, with a Generalized Error Distribution (GED) process for the conditional variance, and a statistically significant GED parameter. The estimates of the volatility from the GARCH models are then plugged in the Black-Scholes formulae. It is worthwhile to note that each currency has a different GARCH specification. Therefore each currency has unique characteristics, and the ensuing regression estimates are not redundant. The second method is justified because variance ratio tests fail to reject the null hypothesis of a martingale, or of a random walk, for the log of each currency (Table 2). The actual p-values are much higher than the $10 \%$ cut-off marginal significance level. This applies for both heteroscedastic robust tests and otherwise, and for both a normal distribution and a bootstrapped normal distribution. This means that all three log-level currencies are random walks, and are unpredictable, even when heteroscedasticity is not accounted for. A surprising finding is that the two methods for measuring volatility produce results that are not materially different.

Table 1. GARCH models of the change in the logs of the three currencies, with a generalized error distribution (GED)

\begin{tabular}{cccc}
\hline & British pound & Swiss franc & Japanese yen \\
\hline Constant & $0.000839(0.602690)$ & $0.001301(0.696274)$ & $0.001295(0.746273)$ \\
\hline $\begin{array}{c}\text { Conditional variance equation } \\
\text { Dependent variable }\end{array}$ & GARCH & LOG(GARCH) & GARCH \\
Constant & $8.80 \mathrm{E}-05(1.571039)$ & $-13.37638(34.8199)$ & $8.26 \mathrm{E}-05(0.378244)$ \\
ARCH(-1) & $0.114779(2.236649)$ & - & - \\
GARCH(-1) & $0.774775(7.505076)$ & - & $0.912856(4.003672)$ \\
LOG(GARCH(-1)) & - & $-0.945303(19.5530)$ & - \\
RESID(-1)/SQRT(GARCH(-1)) & $1.347038(8.834409)$ & $1.780623(8.549434)$ & $1.426006(10.80754)$ \\
\hline GED parameter & & $0.110429(2.365840)$ & - \\
\hline
\end{tabular}

Notes: In parenthesis are absolute t-statistics. The data is monthly from January 1987 to October 2012 for the British pound and from January 1989 to October 2012 for the Swiss franc and the Japanese yen. 
Table 2. Variance ratio tests on the log of each currency (The null hypothesis is a martingale)

\begin{tabular}{|c|c|c|c|c|c|c|c|}
\hline \multirow[b]{2}{*}{ Currency } & $\begin{array}{c}\text { Joint test for } \\
\text { maximum } \\
\mid z-\text { statistic } \mid\end{array}$ & $\begin{array}{c}\text { Joint test for } \\
\text { maximum } \\
\mid z-\text { statistic } \mid\end{array}$ & $\begin{array}{l}\text { Joint test for maximum } \\
\mid z-\text { statistic } \mid \text { using }\end{array}$ & \multicolumn{4}{|c|}{ Variance ratio for period: } \\
\hline & $\begin{array}{c}\mid z-\text { statistic } \mid \\
\text { assuming no } \\
\text { heteroscedasticity }\end{array}$ & $\begin{array}{c}\mid z-\text { statistic } \mid \\
\text { (Lo and } \\
\text { MacKinlay, 1988) }\end{array}$ & $\begin{array}{l}\text { wild bootstrap from } \\
\text { normal distribution } \\
\text { (Kim, 2006) }\end{array}$ & 2 & 6 & 12 & 18 \\
\hline British pound & 0.5508 & 0.9485 & 0.3244 & 1.12777 & 1.18893 & 0.98796 & 0.85345 \\
\hline Swiss franc & 0.9999 & 1.0000 & 0.8926 & 1.04073 & 1.01245 & 0.97010 & 0.86905 \\
\hline Japanese yen & 0.9994 & 0.9993 & 0.6924 & 1.00815 & 1.05206 & 0.91014 & 1.02501 \\
\hline
\end{tabular}

Notes: Bootstrapping is carried out with 5,000 replications. All standard errors are heteroscedastic robust except for the test in the second column. Actual p-values for the maximum absolute z-statistics are reported in columns 2, 3 and 4 . The variance ratios for periods $2,6,12$, and 18 are from heteroscedastic robust standard errors.

The actual option payoffs and the future values of the Black-Scholes call option premiums are tested for stationarity by the Augmented Dickey-Fuller test-statistic (Dickey and Fuller, 1979), with the lags chosen to minimize the Schwarz Information Criterion. The ADF test is known to be sensitive to the number of assumed lags. If $N$ is the sample size, then the maximum number of lags is equal to the integer number of the factor $N^{0.25}$ (Diebold and Nerlove, 1990; Mills, 2000; Mills and Markellos, 2008; Schwert, 1987). Since the sample size is composed of 310 observations for the British pound, this rule provides a result of $310^{0.25}=4.20$, which is rounded to 5. For the other two currencies the rule obtains a result of 4.11, which is also rounded to 5 . All tests include a constant, but not a trend. The tests on the British pound variables indicate, in general, level stationarity (Table 3).

Table 3. Augmented Dickey-Fuller unit root tests with a constant (The maximum lag is set to 5. The null hypothesis is a unit root. The data are for the British pound)

\begin{tabular}{ccccccccc}
\hline \multirow{2}{*}{ Variable } & $\begin{array}{c}\text { Test } \\
\text { statistic }\end{array}$ & $\begin{array}{c}\text { Actual } \\
\text { one-sided } \\
\text { p-value }\end{array}$ & Variable & Test statistic & $\begin{array}{c}\text { Actual } \\
\text { one-sided } \\
\text { p-value }\end{array}$ & Variable & Test statistic & $\begin{array}{c}\text { Actual } \\
\text { one-sided } \\
\text { p-value }\end{array}$ \\
\hline Payoff(1.50) & -3.175566 & 0.0224 & Call(1.50) & -2.815825 & 0.0572 & Call(1.50)c & -3.186943 & 0.0217 \\
Payoff(1.55) & -2.912209 & 0.0451 & Call(1.55) & -3.183191 & 0.0219 & Call(1.55)c & -3.221382 & 0.0197 \\
Payoff(1.60) & -3.268535 & 0.0172 & Call(1.60) & -3.243432 & 0.0185 & Call(1.60)c & -3.278694 & 0.0167 \\
Payoff(1.65) & -3.409746 & 0.0114 & Call(1.65) & -3.353532 & 0.0134 & Call(1.65)c & -3.388550 & 0.0121 \\
Payoff(1.70) & -3.668053 & 0.0050 & Call(1.70) & -3.115240 & 0.0265 & Call(1.70)c & -3.524453 & 0.0080 \\
Payoff(1.75) & -3.652901 & 0.0053 & Call(1.75) & -3.405186 & 0.0115 & Call(1.75)c & -3.408783 & 0.0114 \\
Payoff (1.80) & -3.882375 & 0.0025 & Call(1.80) & -3.611253 & 0.0061 & Call(1.80)c & -3.590351 & 0.0065 \\
\hline
\end{tabular}

Notes: In parenthesis is the strike price. A suffix c stands for calculations based on a fixed monthly volatility of 0.028703 . Otherwise the volatility is estimated from the GARCH model in Table 1 . All call prices are in future values. The data is monthly from January 1987 to October 2012.

Table 4 presents the regression results for the British pound in the case of variable volatility. The adjusted R-Squares are high for monthly data, and they range between 0.828 and 0.901 . The slope estimates are between 0.932 and 0.979 . The null hypotheses that the slopes are equal to +1 fail to be rejected. The minimum actual p-value for these t-tests is 0.1130 . The constants in the seven regressions are all statistically insignificantly different from zero, with a maximum t-statistic of 1.489. For all seven strike prices the joint null hypotheses that the slope is +1 and the constant is zero fail to be rejected. The minimum actual p-value for this Wald F-test is 0.1434. The Ljung-Box Q-statistics do not find autocorrelation in the residuals. Therefore the unbiasedness model is strongly well supported for the British pound. Moreover the unbiasedness relation is valid for both the 
short run and the long run.

Table 4. Ordinary least squares (OLS) regressions (The dependent variables are the payoffs. The independent variables are the future values of the Black-Scholes call option premiums. The volatility is estimated from Table $1 . \mathrm{K}$ is the strike price. The data are for the British pound)

\begin{tabular}{cccccccc}
\hline & $\mathrm{K}=1.50$ & $\mathrm{~K}=1.55$ & $\mathrm{~K}=1.60$ & $\mathrm{~K}=1.65$ & $\mathrm{~K}=1.70$ & $\mathrm{~K}=1.75$ & $\mathrm{~K}=1.80$ \\
\hline Constant & 0.002696 & 0.003568 & 0.001246 & 0.000768 & 0.001628 & 0.001531 & 0.000957 \\
& $(0.790968)$ & $(1.489062)$ & $(0.637359)$ & $(0.458089)$ & $(1.152450)$ & $(1.350823)$ & $(1.099439)$ \\
Slope & 0.979354 & 0.971266 & 0.974643 & 0.972391 & 0.958824 & 0.942180 & 0.932320 \\
& $(53.04545)$ & $(50.14534)$ & $(45.77073)$ & $(40.69567)$ & $(33.72392)$ & $(25.90335)$ & $(20.66952)$ \\
Test for slope=1 & 0.2644 & 0.1390 & 0.2346 & 0.2488 & 0.1486 & 0.1130 & 0.1346 \\
Constant=0 \& Slope=1 & 0.5224 & 0.1920 & 0.4503 & 0.4843 & 0.2020 & 0.1434 & 0.2210 \\
Adjusted R-Square & 0.901198 & 0.898742 & 0.898891 & 0.896014 & 0.877043 & 0.846530 & 0.827704 \\
Durbin-Watson statistic & 1.641852 & 1.688529 & 1.676012 & 1.640998 & 1.709345 & 1.851683 & 1.987857 \\
Q(6) & 0.049 & 0.210 & 0.152 & 0.054 & 0.150 & 0.536 & 0.935 \\
Q(12) & 0.053 & 0.159 & 0.079 & 0.032 & 0.077 & 0.239 & 0.350 \\
Q(24) & 0.130 & 0.192 & 0.199 & 0.216 & 0.330 & 0.444 & 0.575 \\
\hline
\end{tabular}

Notes: HAC standard errors and covariance (Newey and West, 1987). In parenthesis are t-statistics. The separate and joint tests are Wald F-tests. Actual p-values for the tests are reported. $\mathrm{Q}(\mathrm{k})$ is the Ljung-Box Q-statistic for lag length $\mathrm{k}$. Actual p-values for the Q-statistics are reported.

The slope is then constrained to be +1 , and the resulting difference variable, between the payoffs and the future values of the call option premiums, is tested for sationarity and is regressed onto a constant. In all 7 cases the null of non-stationarity is rejected with actual p-values lower than 0.0001 . And in all 7 cases the constant is statistically insignificant. The highest absolute t-statistic is 0.571 .The residuals do not show any serial correlation as judged from the Ljung-Box Q-statistics (Table 5). Hence the orthogonality hypothesis is not rejected. This is further evidence that the model is well specified, and that the unbiasedness hypothesis holds extremely clearly for the British pound in the short and in the long run.

Table 5. Ordinary least squares (OLS) regressions on the constant (The dependent variables are the difference between the actual payoffs and the future values of the call option premiums. The volatility is estimated from Table $1 . \mathrm{K}$ is the strike price. The data are for the British pound)

\begin{tabular}{cccccccc}
\hline & $\mathrm{K}=1.50$ & $\mathrm{~K}=1.55$ & $\mathrm{~K}=1.60$ & $\mathrm{~K}=1.65$ & $\mathrm{~K}=1.70$ & $\mathrm{~K}=1.75$ & $\mathrm{~K}=1.80$ \\
\hline Dickey-Fuller test & -14.83620 & -15.24081 & -15.08571 & -14.81339 & -15.41078 & -11.89423 & -17.98823 \\
& {$[0.0000]$} & {$[0.0000]$} & {$[0.0000]$} & {$[0.0000]$} & {$[0.0000]$} & {$[0.0000]$} & {$[0.0000]$} \\
Constant & -0.000848 & -0.000158 & -0.001191 & -0.001175 & -0.000477 & -0.000556 & -0.000682 \\
& $(0.273680)$ & $(0.057516)$ & $(0.480359)$ & $(0.539470)$ & $(0.254002)$ & $(0.362045)$ & $(0.571066)$ \\
Durbin-Watson statistic & 1.667805 & 1.721841 & 1.706306 & 1.673864 & 1.754285 & 1.911358 & 2.062131 \\
$\mathrm{Q}(6)$ & 0.102 & 0.277 & 0.165 & 0.054 & 0.134 & 0.358 & 0.626 \\
$\mathrm{Q}(12)$ & 0.091 & 0.175 & 0.075 & 0.027 & 0.053 & 0.134 & 0.167 \\
$\mathrm{Q}(24)$ & 0.167 & 0.175 & 0.177 & 0.189 & 0.247 & 0.281 & 0.359 \\
\hline
\end{tabular}

Notes: Actual p-values are in brackets. Absolute t-statistics are in parenthesis, computed with the HAC standard errors and covariance correction (Newey and West, 1987). Q(k) are the Ljung-Box Q-statistics for lag length k. Actual p-values for the Q-statistics are reported.

Table 6 presents the regression results for the British pound in the case of constant volatility. The adjusted R-Squares are again high for monthly data, and they range between 0.828 and 0.903 . The slope estimates are 
between 0.932 and 0.976 . The null hypotheses that the slopes are equal to +1 fail to be rejected. The minimum actual $\mathrm{p}$-value for these t-tests is 0.0844 . Six constants out of seven are statistically insignificantly different from zero. For all seven strike prices the joint null hypotheses that the slope is +1 and the constant is zero fail to be rejected. The minimum actual p-value for this Wald F-test is 0.0840 . The Ljung-Box Q-statistics do not find autocorrelation in the residuals. Therefore the unbiasedness model is strongly well supported, and the results are not sensitive to the assumption about the volatility.

Table 6. Ordinary least squares (OLS) regressions (The dependent variables are the actual payoffs. The independent variables are the future values of the call option premiums. The monthly volatility is set at 0.028703 . $\mathrm{K}$ is the strike price. The data are for the British pound)

\begin{tabular}{cccccccc}
\hline & $\mathrm{K}=1.50$ & $\mathrm{~K}=1.55$ & $\mathrm{~K}=1.60$ & $\mathrm{~K}=1.65$ & $\mathrm{~K}=1.70$ & $\mathrm{~K}=1.75$ & $\mathrm{~K}=1.80$ \\
\hline Constant & 0.006506 & 0.003504 & 0.000925 & 0.000581 & 0.001676 & 0.001626 & 0.000993 \\
& $(2.119804)$ & $(1.460550)$ & $(0.463759)$ & $(0.341849)$ & $(1.180934)$ & $(1.435512)$ & $(1.136402)$ \\
Slope & 0.968098 & 0.971484 & 0.975772 & 0.973351 & 0.959065 & 0.942057 & 0.932392 \\
& $(52.52587)$ & $(49.49802)$ & $(45.39479)$ & $(40.57812)$ & $(33.70735)$ & $(25.88018)$ & $(20.65516)$ \\
Test for slope=1 & 0.0844 & 0.1472 & 0.2606 & 0.2674 & 0.1512 & 0.1124 & 0.1352 \\
Constant=0 \& Slope=1 & 0.0840 & 0.2122 & 0.5173 & 0.5289 & 0.2035 & 0.1321 & 0.2166 \\
Adjusted R-Square & 0.902690 & 0.899018 & 0.898857 & 0.896027 & 0.877380 & 0.846884 & 0.827964 \\
Durbin-Watson statistic & 1.690159 & 1.699236 & 1.679952 & 1.642903 & 1.712289 & 1.855810 & 1.985614 \\
Q(6) & 0.182 & 0.246 & 0.171 & 0.060 & 0.147 & 0.494 & 0.912 \\
Q(12) & 0.133 & 0.174 & 0.083 & 0.032 & 0.077 & 0.230 & 0.353 \\
Q(24) & 0.250 & 0.210 & 0.210 & 0.207 & 0.312 & 0.421 & 0.571 \\
\hline
\end{tabular}

Notes: HAC standard errors and covariance (Newey and West, 1987). In parenthesis are t-statistics. All the tests are Wald F-tests. Actual p-values for the tests are reported. See the notes under Table 5 for further information.

Table 7. Ordinary least squares (OLS) regressions on the constant (The dependent variables are the difference between the actual payoffs and the future values of the call option premiums. The monthly volatility is set at 0.028703. $\mathrm{K}$ is the strike price. The data are for the British pound)

\begin{tabular}{cccccccc}
\hline & $\mathrm{K}=1.50$ & $\mathrm{~K}=1.55$ & $\mathrm{~K}=1.60$ & $\mathrm{~K}=1.65$ & $\mathrm{~K}=1.70$ & $\mathrm{~K}=1.75$ & $\mathrm{~K}=1.80$ \\
\hline Dickey-Fuller test & -15.30477 & -15.33321 & -15.11973 & -14.82964 & -15.43609 & -16.71616 & -17.96863 \\
& {$[0.0000]$} & {$[0.0000]$} & {$[0.0000]$} & {$[0.0000]$} & {$[0.0000]$} & {$[0.0000]$} & {$[0.0000]$} \\
Constant & 0.001092 & -0.000195 & -0.001409 & -0.001297 & -0.000414 & -0.000460 & -0.000641 \\
& $(0.378075)$ & $(0.072090)$ & $(0.571166)$ & $(0.597479)$ & $(0.222480)$ & $(0.302616)$ & $(0.538104)$ \\
Durbin-Watson statistic & 1.726280 & 1.732721 & 1.709518 & 1.675174 & 1.757246 & 1.915686 & 2.058990 \\
Q(6) & 0.257 & 0.290 & 0.182 & 0.057 & 0.121 & 0.298 & 0.584 \\
Q(12) & 0.160 & 0.179 & 0.081 & 0.029 & 0.050 & 0.118 & 0.165 \\
$\mathrm{Q}(24)$ & 0.246 & 0.186 & 0.192 & 0.187 & 0.221 & 0.252 & 0.361 \\
\hline
\end{tabular}

Notes: HAC standard errors and covariance (Newey and West, 1987). Actual p-values are in brackets. Absolute t-statistics are in parenthesis. $\mathrm{Q}(\mathrm{k})$ are the Ljung-Box Q-statistics for lag length k. Actual p-values for the Q-statistics are reported.

The slope is then constrained to be +1 , and the resulting difference variable, between the actual payoffs and the future values of the Black-Scholes call option premiums, is tested for stationarity and is regressed onto a constant. In all 7 cases the null of non-stationarity is rejected at a cut-off marginal significance level lower than 0.0001 . And in all 7 cases the constant is statistically insignificant. Again the residuals do not show any serial correlation (Table 7). This is further evidence that the model is well specified, that the unbiasedness hypothesis holds extremely well in the short and in the long run and that the assumption about the volatility is not crucial.

In Table 8 Dickey-Fuller unit root tests on the Swiss franc variables are reported. Contrary to the evidence for the 
British pound, all these Swiss franc variables have unit roots. All the actual payoffs and all the future values of the call options need first-differencing to become stationary. The minimum p-value for the level variables is 0.271 , which is higher than the usual cut-off marginal significance level of $10 \%$. The p-values for the first-differenced variables are all lower than 0.0001. This is testimony to the observation that the three currencies under study have each a different statistical behavior and that the tests that are carried out are not redundant. Therefore the regressions of the actual pay-offs on the future values of the call option premiums should be considered as cointegration regressions and must be tested for the presence of cointegration.

Table 8. Augmented Dickey-Fuller unit root tests with a constant (The maximum lag is set to 5. The null hypothesis is a unit root. The data are for the Swiss franc. The variable volatility is retrieved from the GARCH model in Table 1 . The suffix c denotes a constant volatility. The constant monthly volatility is set at $0.032646 . \Delta$ is the first-difference operator)

\begin{tabular}{|c|c|c|c|c|c|c|c|c|}
\hline Variable & $\begin{array}{c}\text { Test } \\
\text { statistic }\end{array}$ & $\begin{array}{c}\text { Actual } \\
\text { one-sided } \\
\text { p-value }\end{array}$ & Variable & $\begin{array}{c}\text { Test } \\
\text { statistic }\end{array}$ & $\begin{array}{c}\text { Actual } \\
\text { one-sided } \\
\text { p-value }\end{array}$ & Variable & $\begin{array}{c}\text { Test } \\
\text { statistic }\end{array}$ & $\begin{array}{c}\text { Actual } \\
\text { one-sided } \\
\text { p-value }\end{array}$ \\
\hline Payoff(0.65) & -2.114740 & 0.5349 & Call(0.65) & -2.118804 & 0.5326 & Call(0.65)c & -2.118693 & 0.5327 \\
\hline$\Delta$ Payoff(0.65) & $-16,93936$ & 0.0000 & $\Delta \operatorname{Call}(0.65)$ & -16.89632 & 0.0000 & $\Delta$ Call $(0.65) \mathrm{c}$ & -16.91174 & 0.0000 \\
\hline Payoff(0.70) & -2.199217 & 0.4877 & Call(0.70) & -2.194232 & 0.4905 & Call $(0.70) \mathrm{c}$ & -2.190579 & 0.4925 \\
\hline$\Delta$ Payoff $(0.70)$ & -17.62994 & 0.0000 & $\Delta \operatorname{Call}(0.70)$ & -17.56284 & 0.0000 & $\Delta$ Call $(0.70) \mathrm{c}$ & -17.55345 & 0.0000 \\
\hline Payoff(0.75) & -2.237133 & 0.4667 & Call(0.75) & -2.240222 & 0.4649 & Call $(0.75) \mathrm{c}$ & -2.236411 & 0.4671 \\
\hline$\Delta$ Payoff(0.75) & -18.36698 & 0.0000 & $\Delta \operatorname{Call}(0.75)$ & -18.34262 & 0.0000 & $\Delta \operatorname{Call}(0.75) \mathrm{c}$ & -18.30717 & 0.0000 \\
\hline Payoff (0.80) & -2.251552 & 0.4587 & Call(0.80) & -2.273830 & 0.4464 & Call(0.80)c & -2.262090 & 0.4529 \\
\hline$\Delta$ Payoff(0.80) & -19.13002 & 0.0000 & $\Delta \operatorname{Call}(0.80)$ & -19.04268 & 0.0000 & $\Delta$ Call $(0.80) \mathrm{c}$ & -18.97337 & 0.0000 \\
\hline Payoff(0.85) & -2.266804 & 0.4503 & Call(0.85) & -2.280866 & 0.4426 & Call(0.85)c & -2.264467 & 0.4516 \\
\hline$\Delta$ Payoff(0.85) & -18.77908 & 0.0000 & $\Delta$ Call $(0.85)$ & -18.67838 & 0.0000 & $\Delta$ Call $(0.85) \mathrm{c}$ & -18.59153 & 0.0000 \\
\hline Payoff(0.90) & -2.242222 & 0.4639 & Call(0.90) & -2.292791 & 0.4361 & Call(0.90)c & -2.285949 & 0.4398 \\
\hline$\Delta$ Payoff(0.90) & -17.27104 & 0.0000 & $\Delta$ Call $(0.90)$ & -17.48243 & 0.0000 & $\Delta$ Call $(0.90) \mathrm{c}$ & -17.45483 & 0.0000 \\
\hline Payoff (0.95) & -2.605446 & 0.2783 & Call(0.95) & -2.621571 & 0.2710 & Call(0.95)c & -2.615970 & 0.2735 \\
\hline$\Delta$ Payoff(0.95) & -9.283800 & 0.0000 & $\Delta \operatorname{Call}(0.95)$ & -9.435990 & 0.0000 & $\Delta$ Call $(0.95) \mathrm{c}$ & -9.468061 & 0.0000 \\
\hline
\end{tabular}

Table 9. Augmented Dickey-Fuller unit root tests with a constant (The maximum lag is set to 5. The null hypothesis is a unit root. The data are for the Japanese yen (in US cents per one yen). The variable volatility is retrieved from the GARCH model in Table 1 . The suffix c denotes a constant volatility. The constant monthly volatility is set at 0.031424 )

\begin{tabular}{|c|c|c|c|c|c|c|c|c|}
\hline Variable & $\begin{array}{c}\text { Test } \\
\text { statistic }\end{array}$ & $\begin{array}{c}\text { Actual } \\
\text { one-sided } \\
\text { p-value }\end{array}$ & Variable & Test statistic & $\begin{array}{c}\text { Actual } \\
\text { one-sided } \\
\text { p-value }\end{array}$ & Variable & Test statistic & $\begin{array}{c}\text { Actual } \\
\text { one-sided } \\
\text { p-value }\end{array}$ \\
\hline Payoff(0.70) & -1.829678 & 0.6878 & Call(0.70) & -1.704517 & 0.7470 & Call(0.70)c & -1.705672 & 0.7465 \\
\hline$\Delta$ Payoff(0.70) & -16.61495 & 0.0000 & $\Delta \operatorname{Call}(0.70)$ & -16.51708 & 0.0000 & $\Delta \operatorname{Call}(0.70) \mathrm{c}$ & -16.52258 & 0.0000 \\
\hline Payoff(0.75) & -1.746888 & 0.7277 & Call(0.75) & -1.605603 & 0.7887 & Call $(0.75) \mathrm{c}$ & -1.605060 & 0.7889 \\
\hline$\Delta$ Payoff(0.75) & -16.61151 & 0.0000 & $\Delta \operatorname{Call}(0.75)$ & -16.52247 & 0.0000 & $\Delta \operatorname{Call}(0.75) \mathrm{c}$ & -16.52435 & 0.0000 \\
\hline Payoff (0.80) & -1.623244 & 0.7816 & Call(0.80) & -1.444730 & 0.8457 & Call $(0.80) \mathrm{c}$ & -1.442892 & 0.8463 \\
\hline$\Delta$ Payoff(0.80) & -16.49942 & 0.0000 & $\Delta \operatorname{Call}(0.80)$ & -16.39192 & 0.0000 & $\Delta \operatorname{Call}(0.80) \mathrm{c}$ & -16.38834 & 0.0000 \\
\hline Payoff(0.85) & -1.440921 & 0.8469 & Call(0.85) & -1.262893 & 0.8945 & Call $(0.85) \mathrm{c}$ & -2.264467 & 0.4516 \\
\hline$\Delta$ Payoff(0.85) & -16.14398 & 0.0000 & $\Delta$ Call $(0.85)$ & -16.13649 & 0.0000 & $\Delta$ Call $(0.85) \mathrm{c}$ & -18.59153 & 0.0000 \\
\hline Payoff(0.90) & -1.498711 & 0.8281 & Call(0.90) & -1.219827 & 0.9039 & Call $(0.90) \mathrm{c}$ & -2.285949 & 0.4398 \\
\hline$\Delta$ Payoff(0.90) & -16.39310 & 0.0000 & $\Delta \operatorname{Call}(0.90)$ & -16.14653 & 0.0000 & $\Delta \operatorname{Call}(0.90) \mathrm{c}$ & -17.45483 & 0.0000 \\
\hline Payoff (0.95) & -1.459473 & 0.8411 & Call(0.95) & -1.159049 & 0.9158 & Call $(0.95) \mathrm{c}$ & -2.615970 & 0.2735 \\
\hline$\Delta$ Payoff(0.95) & -15.58521 & 0.0000 & $\Delta$ Call(0.95) & -15.49606 & 0.0000 & $\Delta \operatorname{Call}(0.95) \mathrm{c}$ & -9.468061 & 0.0000 \\
\hline Payoff (1.00) & -1.668801 & 0.7626 & Call(1.00) & -1.285841 & 0.8892 & Call(1.00)c & -1.283989 & 0.8896 \\
\hline$\Delta$ Payoff(1.00) & -15.07124 & 0.0000 & $\Delta$ Call(1.00) & -15.37934 & 0.0000 & $\Delta$ Call $(1.00) \mathrm{c}$ & -15.38840 & 0.0000 \\
\hline
\end{tabular}

In Table 9 Dickey-Fuller unit root tests on the yen variables are reported. Contrary to the British pound, but similarly to the Swiss franc, all yen level variables need first-differencing to become stationary. Hence regressions of the actual payoffs on the future values of the call options must be considered cointegration 
regressions and must be tested for the presence of cointegration.

In Table 10 OLS regressions of the basic model for the Swiss franc (Panel A) and the Japanese yen (Panel B) are carried out. Included are results when the volatilities are considered variable and when they are set to be constants, equal to the sample standard deviations. In all 28 cases and for each one of the Engle-Granger and the Phillips-Ouliaris residual tests for cointegration the null of no-cointegration is rejected at marginal significance levels less than 0.0001. For these two tests see Engle and Granger (1987), and Phillips and Ouliaris (1990). Hence, the evidence is strong for cointegration, and for long run relations. The adjusted R-squares are all high for monthly data and they range between 0.914 and 0.966 . Hypothesis tests are implemented on the estimated coefficients. In all 28 cases the constants are statistically insignificantly different from zero, with a minimum p-value of 0.2945 . In all 28 cases the slopes are statistically insignificantly different from +1 , with a minimum p-value of 0.5730 . And in all 28 cases the joint null hypotheses of a zero constant and a unitary positive slope fail to be rejected, with a minimum p-value of 0.5766 . The results are not sensitive to the method by which volatility is measured. First-order serial correlations of the cointegration residuals are generally absent for all regressions, the lowest Durbin-Watson statistic being 1.759 and the highest being 2.208. However high-order serial correlations are statistically significant. The latter may prompt the researcher to doubt the validity of hypothesis testing. In fact there are two reasons that imply that hypothesis tests are still valid. The first one is because robust standard errors to the presence of residual autocorrelation and heteroscedasticity of unknown origins are calculated according to the adjustment formulated by Newey and West (1987). The second one is because residual serial correlations bias the standard errors downward. This means that the tests on the nulls of the hypotheses will reject these nulls more frequently than otherwise. Hence the evidence that the null hypotheses are not rejected despite serial correlation indicates even stronger confidence, and therefore more reliability, in these hypothesis tests.

In Hull (2012, p. 355) the lower bound on European currency options is stated, and this is:

$$
C_{t} \geq \operatorname{Max}\left[S_{t} e^{-r f T}-K e^{-r T}, 0\right]
$$

A sample of the generated Black-Scholes currency call premiums is studied, and the constraint in equation (8) is tested. The sample contains options with different strike prices and with the two different measures of the volatility. It is found that this constraint is binding for the chosen sample. Therefore the empirical analysis in this paper is sound.

Table 10. Hypotheses tests on Ordinary least squares (OLS) regressions. (The dependent variables are the actual payoffs. The independent variables are the future values of the call option premiums. The actual p-values of the different tests are reported, except for the Durbin-Watson statistics. The first row is for the variables with variable volatility, and the second row is for the variables with constant volatility)

PANEL A. The independent variable is call $(\mathrm{K})$ for the first row and call $(\mathrm{K}) \mathrm{c}$ for the second row

The data are for the Swiss franc.

\begin{tabular}{|c|c|c|c|c|c|c|c|}
\hline & $\mathrm{K}=0.65$ & $\mathrm{~K}=0.70$ & $\mathrm{~K}=0.75$ & $\mathrm{~K}=0.80$ & $\mathrm{~K}=0.85$ & $\mathrm{~K}=0.90$ & $\mathrm{~K}=0.95$ \\
\hline \multirow[t]{2}{*}{ Test for constant $=0$} & 0.4595 & 0.6675 & 0.5820 & 0.9508 & 0.5295 & 0.3018 & 0.4002 \\
\hline & 0.4676 & 0.6836 & 0.5838 & 0.9759 & 0.5474 & 0.2945 & 0.4010 \\
\hline \multirow[t]{2}{*}{ Test for slope $=1$} & 0.5829 & 0.6872 & 0.6655 & 0.7022 & 0.6422 & 0.6450 & 0.5730 \\
\hline & 0.5869 & 0.6931 & 0.6664 & 0.7079 & 0.6492 & 0.6464 & 0.5763 \\
\hline \multirow[t]{2}{*}{ Constant $=0$ \& Slope $=1$} & 0.7601 & 0.8995 & 0.8517 & 0.9199 & 0.8002 & 0.5860 & 0.6787 \\
\hline & 0.7675 & 0.9066 & 0.8529 & 0.9183 & 0.8134 & 0.5766 & 0.6802 \\
\hline \multirow[t]{2}{*}{ Adjusted R-Square } & 0.963848 & 0.962107 & 0.957840 & 0.950727 & 0.942960 & 0.936991 & 0.914347 \\
\hline & 0.963854 & 0.962139 & 0.957886 & 0.950769 & 0.943424 & 0.937203 & 0.914523 \\
\hline \multirow[t]{2}{*}{ Engle-Granger tau test } & 0.0000 & 0.0000 & 0.0000 & 0.0000 & 0.0000 & 0.0049 & 0.0000 \\
\hline & 0.0000 & 0.0000 & 0.0000 & 0.0000 & 0.0000 & 0.0002 & 0.0000 \\
\hline \multirow{2}{*}{$\begin{array}{l}\text { Phillips-Ouliaris } \\
\text { tau test }\end{array}$} & 0.0000 & 0.0000 & 0.0000 & 0.0000 & 0.0000 & 0.0000 & 0.0000 \\
\hline & 0.0000 & 0.0000 & 0.0000 & 0.0000 & 0.0000 & 0.0000 & 0.0000 \\
\hline \multirow[t]{2}{*}{ Durbin-Watson statistic } & 1.989820 & 2.062250 & 2.158063 & 2.208429 & 2.170596 & 2.038733 & 2.098854 \\
\hline & 1.989066 & 2.058456 & 2.154692 & 2.202544 & 2.160819 & 2.036266 & 2.092535 \\
\hline $\mathrm{Q}(6)$ & 0.262 & 0.125 & 0.012 & 0.001 & 0.000 & 0.005 & 0.000 \\
\hline $\mathrm{Q}(12)$ & 0.301 & 0.129 & 0.004 & 0.000 & 0.000 & 0.000 & 0.000 \\
\hline \multirow[t]{4}{*}{$\mathrm{Q}(24)$} & 0.321 & 0.080 & 0.000 & 0.000 & 0.000 & 0.000 & 0.000 \\
\hline & 0.268 & 0.127 & 0.011 & 0.002 & 0.000 & 0.005 & 0.000 \\
\hline & 0.302 & 0.132 & 0.004 & 0.000 & 0.000 & 0.000 & 0.000 \\
\hline & 0.325 & 0.078 & 0.000 & 0.000 & 0.000 & 0.000 & 0.000 \\
\hline
\end{tabular}


PANEL B. The independent variable is call $(\mathrm{K})$ for the first row and call $(\mathrm{K}) \mathrm{c}$ for the second row.

The data are for the Japanese yen

\begin{tabular}{cccccccc}
\hline & $\mathrm{K}=0.70$ & $\mathrm{~K}=0.75$ & $\mathrm{~K}=0.80$ & $\mathrm{~K}=0.85$ & $\mathrm{~K}=0.90$ & $\mathrm{~K}=0.95$ & $\mathrm{~K}=1.00$ \\
\hline Test for constant $=0$ & 0.7591 & 0.9234 & 0.8652 & 0.4382 & 0.7674 & 0.6207 & 0.5677 \\
& 0.7352 & 0.9126 & 0.8521 & 0.4097 & 0.7248 & 0.5787 & 0.5996 \\
Test for slope=1 & 0.6067 & 0.6807 & 0.7628 & 0.9692 & 0.7707 & 0.8312 & 0.5993 \\
& 0.5911 & 0.6748 & 0.7685 & 0.9838 & 0.7805 & 0.8388 & 0.6026 \\
Constant=0 \& Slope=1 & 0.8661 & 0.8941 & 0.8953 & 0.7081 & 0.9105 & 0.8721 & 0.6863 \\
& 0.8587 & 0.8935 & 0.8924 & 0.6810 & 0.8963 & 0.8468 & 0.7104 \\
Adjusted R-Square & 0.964455 & 0.964826 & 0.965138 & 0.965658 & 0.961890 & 0.960182 & 0.950982 \\
& 0.964468 & 0.964857 & 0.965151 & 0.965643 & 0.961893 & 0.960149 & 0.950975 \\
Engle-Granger tau test & 0.0000 & 0.0000 & 0.0000 & 0.0000 & 0.0000 & 0.0000 & 0.0000 \\
& 0.0000 & 0.0000 & 0.0000 & 0.0000 & 0.0000 & 0.0000 & 0.0000 \\
Phillips-Ouliaris tau test & 0.0000 & 0.0000 & 0.0000 & 0.0000 & 0.0000 & 0.0000 & 0.0000 \\
Durbin-Watson statistic & 0.0000 & 0.0000 & 0.0000 & 0.0000 & 0.0000 & 0.0000 & 0.0000 \\
& 1.914053 & 1.908455 & 1.914090 & 1.863961 & 1.879674 & 1.783993 & 1.759274 \\
$\mathrm{Q}(6)$ & 1.915411 & 1.909377 & 1.913749 & 1.863104 & 1.878226 & 1.782053 & 1.758635 \\
$\mathrm{Q}(12)$ & 0.117 & 0.144 & 0.166 & 0.039 & 0.045 & 0.015 & 0.001 \\
$\mathrm{Q}(24)$ & 0.004 & 0.010 & 0.023 & 0.005 & 0.012 & 0.015 & 0.000 \\
& 0.017 & 0.013 & 0.029 & 0.002 & 0.001 & 0.001 & 0.000 \\
& 0.117 & 0.144 & 0.166 & 0.039 & 0.045 & 0.016 & 0.001 \\
& 0.004 & 0.010 & 0.022 & 0.005 & 0.012 & 0.015 & 0.000 \\
\hline
\end{tabular}

Table 11. Ordinary least squares (OLS) regressions on the constant (The dependent variables are the difference between the actual payoffs and the future values of the call option premiums. The first row is for the variables with variable volatility, and the second row is for the variables with constant volatility. The Dickey-Fuller tests are on the difference variables. $\mathrm{K}$ is the strike price. All cell entries are actual p-values, except for the Durbin-Watson statistic)

PANEL A. Swiss franc

\begin{tabular}{|c|c|c|c|c|c|c|c|}
\hline & $\mathrm{K}=0.65$ & $\mathrm{~K}=0.70$ & $\mathrm{~K}=0.75$ & $\mathrm{~K}=0.80$ & $\mathrm{~K}=0.85$ & $\mathrm{~K}=0.90$ & $\mathrm{~K}=0.95$ \\
\hline \multirow[t]{2}{*}{ Dickey-Fuller test } & 0.0000 & 0.0000 & 0.0000 & 0.0000 & 0.0000 & 0.0000 & 0.0000 \\
\hline & 0.0000 & 0.0000 & 0.0000 & 0.0000 & 0.0000 & 0.0000 & 0.0000 \\
\hline \multirow[t]{2}{*}{ Constant $=0$} & 0.8419 & 0.9652 & 0.9786 & 0.7069 & 0.9741 & 0.8293 & 0.9442 \\
\hline & 0.8483 & 0.9549 & 0.9781 & 0.6948 & 0.9665 & 0.8201 & 0.9507 \\
\hline \multirow{2}{*}{$\begin{array}{c}\text { Durbin-Watson } \\
\text { statistic }\end{array}$} & 2.002840 & 2.074125 & 2.173457 & 2.226039 & 2.194925 & 2.066886 & 2.141276 \\
\hline & 2.001978 & 2.070109 & 2.169998 & 2.219728 & 2.184452 & 2.064179 & 2.134507 \\
\hline $\mathrm{Q}(6)$ & 0.250 & 0.119 & 0.010 & 0.002 & 0.000 & 0.004 & 0.000 \\
\hline $\mathrm{Q}(12)$ & 0.260 & 0.104 & 0.002 & 0.000 & 0.000 & 0.000 & 0.000 \\
\hline \multirow[t]{4}{*}{$\mathrm{Q}(24)$} & 0.301 & 0.068 & 0.000 & 0.000 & 0.000 & 0.000 & 0.000 \\
\hline & 0.256 & 0.122 & 0.010 & 0.002 & 0.000 & 0.003 & 0.000 \\
\hline & 0.262 & 0.107 & 0.002 & 0.000 & 0.000 & 0.000 & 0.000 \\
\hline & 0.306 & 0.067 & 0.000 & 0.000 & 0.000 & 0.000 & 0.000 \\
\hline
\end{tabular}

PANEL B. Japanese yen

\begin{tabular}{|c|c|c|c|c|c|c|c|}
\hline & $\mathrm{K}=0.70$ & $\mathrm{~K}=0.75$ & $\mathrm{~K}=0.80$ & $\mathrm{~K}=0.85$ & $\mathrm{~K}=0.90$ & $\mathrm{~K}=0.95$ & $\mathrm{~K}=1.00$ \\
\hline Dickey-Fuller & 0.0000 & 0.0000 & 0.0000 & 0.0000 & 0.0000 & 0.0000 & 0.0000 \\
\hline test & 0.0000 & 0.0000 & 0.0000 & 0.0000 & 0.0000 & 0.0000 & 0.0000 \\
\hline \multirow[t]{2}{*}{ Constant $=0$} & 0.7942 & 0.7207 & 0.6440 & 0.4665 & 0.6621 & 0.6236 & 0.9594 \\
\hline & 0.8061 & 0.7264 & 0.6369 & 0.4480 & 0.6381 & 0.5974 & 0.9821 \\
\hline Durbin-Watson & 1.923833 & 1.916455 & 1.920246 & 1.864884 & 1.886644 & 1.789729 & 1.773335 \\
\hline statistic & 1.925514 & 1.917504 & 1.919763 & 1.863593 & 1.884916 & 1.787544 & 1.772585 \\
\hline $\mathrm{Q}(6)$ & 0.104 & 0.131 & 0.156 & 0.039 & 0.038 & 0.013 & 0.000 \\
\hline $\mathrm{Q}(12)$ & 0.005 & 0.012 & 0.026 & 0.005 & 0.013 & 0.015 & 0.000 \\
\hline \multirow[t]{4}{*}{$\mathrm{Q}(24)$} & 0.020 & 0.015 & 0.032 & 0.002 & 0.001 & 0.001 & 0.000 \\
\hline & 0.104 & 0.130 & 0.156 & 0.039 & 0.039 & 0.014 & 0.000 \\
\hline & 0.005 & 0.012 & 0.025 & 0.005 & 0.013 & 0.015 & 0.000 \\
\hline & 0.020 & 0.015 & 0.031 & 0.002 & 0.001 & 0.001 & 0.000 \\
\hline
\end{tabular}

In Table 11, as in Table 7, the theoretical constraint that the slope is exactly +1 is imposed. The Dickey-Fuller unit root tests on the ensuing difference variables are applied. In all 28 cases the tests reject the null of non-stationarity at marginal significance levels lower than 0.0001 . It can be concluded that assuming a slope equal to +1 provides evidence that the cointegration coefficients are indeed +1 . Then these difference variables are regressed on a constant. The null hypotheses that each of the 28 constants is statistically insignificantly 
different from zero fail to be rejected. This supports the evidence on long run unbiasedness. First-order serial correlation of the residuals is generally absent, the lowest Durbin-Watson statistic being 1.773, and the highest being 2.220. However higher-order serial correlation is significant in most cases. This mirrors the results obtained by the unconstrained regressions in Table 10.

\section{Conclusion}

In this paper, the unbiasedness hypothesis is tested for Black-Sholes currency call option premiums. Three currencies are tested, each with seven different strike prices. Unbiasedness implies that the future value of a call option premium is an unbiased predictor of the future actual option payoff. Unbiasedness is supported if the regression constants are statistically insignificant, if the regression slopes are statistically insignificantly different from 1 , and if there is no serial correlation in the regression residuals, meaning that there is orthogonality in the residuals. The results are strongly supportive for this version of currency option market efficiency in the case of the British pound. The results remain also strongly supportive when the theoretical constraints are imposed. As for the other two currencies, the Swiss franc and the Japanese yen, the null hypotheses of no-cointegration are rejected and hence a long run relation is well supported. Cointegration is a weaker condition for unbiasedness because it is a characteristic of only a long run relation. However, the theoretical constraints in the cointegration regressions hold also for these two currencies, although orthogonality of the residuals is naturally rejected. In addition, the results are not materially different with alternative measures of currency volatility. As a conclusion the Black-Scholes option pricing model is still robust, practical, useful, appropriate, and relevant.

\section{References}

Azar, S. A. (2008). Jensen's inequality in finance. International Advances in Economic Research, 14, 433-440. http://dx.doi.org/10.1007/s11294-008-9172-9

Baillie, R. T., \& Bollerslev, T. (1989). The message in daily exchange rates: a conditional-variance tale. Journal of Business \& Economic Statistics, 7, 297-305. http://dx.doi.org/10.2307/1391527

Biger, N., \& Hull, J. C. (1983). The valuation of currency options. Financial Management, 12, $24-28$. http://dx.doi.org/10.2307/3664834

Black, F., \& Scholes, M. (1973). The pricing of options and corporate liabilities. Journal of Political Economy, 81, 637-659. http://dx.doi.org/10.1086/260062

Bollerslev, T. (1986). Generalised autoregressive conditional heteroskedasticity. Journal of Econometrics, 31, 307-327. http://dx.doi.org/10.1016/0304-4076(86)90063-1

Chesney, M., \& Scott, L. (1989). Pricing European currency options: a comparison of the modified Black-Scholes model and a random variance model. Journal of Financial and Quantitative Analysis, 24, 267-284. http://dx.doi.org/10.2307/2330812

Dash, M., Dagha, J. H., Sharma, P., \& Singhal, R. (2012). An application of GARCH models in detecting systematic bias in options pricing and determining arbitrage in options. Journal of CENTRUM Cathedra, 5 , 91-101. http://dx.doi.org/10.7835/jcc-berj-2012-0069

Dickey, D. A., \& Fuller, W. A. (1979). Distribution of the estimators for autoregressive time series with a unit root. Journal of the American Statistical Association, 74, 427-431. http://dx.doi.org/10.2307/2286348

Diebold, F. X., \& Nerlove, M. (1990). Unit roots in economic time series: a selective survey. In Rhodes, G. F., \& Fomby, T. B. (Eds.), Advances in econometrics (pp. 3-69). J Greenwich: JAI Press.

Duan, J. C., \& Simonato, J. G. (1998). Empirical martingale simulation for asset prices. Management Science, 44(9). 1218-1233. http://dx.doi.org/10.1287/mnsc.44.9.1218

Dupoyet, B. (2006). Information content of cross-sectional option prices: A comparison of alternative currency option pricing models on the Japanese yen. The Journal of Futures Markets, 26, 33-59. http://dx.doi.org/10.1002/fut.20177

Engle, R. F. (1982). Autoregressive conditional heteroskedasticity with estimates of the variance of U.K. inflation. Econometrica, 50, 987-1008. http://dx.doi.org/10.2307/1912773

Engle, R. F., \& Granger, C. W. J. (1987). Co-integration and error correction: representation, estimation, and testing. Econometrica, 55, 271-276. http://dx.doi.org/10.2307/1913236

Garman, M. B., \& Kohlhagen, S. W. (1983). Foreign currency option values. Journal of International Money and Finance, 2, 231-237. http://dx.doi.org/10.1016/S0261-5606(83)80001-1 
Grabbe, J. (1983). The pricing of call and put options on foreign exchange. Journal of International Money and Finance, 2, 239-254. http://dx.doi.org/10.1016/S0261-5606(83)80002-3

Harikumar, T., De Boyrie, M., \& Pak, S. J. (2004). Evaluation of Black-Scholes and GARCH models using currency call option data. Review of Quantitative Finance and Accounting, 23, 299-312. http://dx.doi.org/10.1023/B:REQU.0000049318.78363.3c

Hoque, A., Chan, F., \& Manzur, M. (2008). Efficiency of foreign currency options market. Global Finance Journal, 19, 157-170. http://dx.doi.org/10.1016/j.gfj.2008.02.002

Hull, J. C. (2012). Options, futures, and other derivatives (8th ed.). Upper Saddle River: Pearson, Prentice.

HallKim, J. H. (2006). Wild bootstrapping variance ratio tests. Economics Letters, 92, 38-43. http://dx.doi.org/10.1016/j.econlet.2006.01.007

Ljung, G. M., \& Box, G. E. P. (1978). On a measure of lack of fit in time series models. Biometrika, 65, 297-303. http://dx.doi.org/10.1093/biomet/65.2.297

Lo, A. W., \& MacKinlay, A. C. (1988). Stock market prices do not follow random walks: Evidence from a simple specification test. The Review of Financial Studies, 1, 41-66. http://dx.doi.org/10.1093/rfs/1.1.41

Manzur, M., Hoque, A., \& Poitras, G. (2010). Currency option pricing and realized volatility. Banking and Finance Review, 1, 73-85.

Merton, R. C. (1973). Theory of rational option pricing. The Bell Journal of Economics and Management Science, 4, 141-183. http://dx.doi.org/10.2307/3003143

Mills, T. C. (2000). The econometric modelling of financial time series (2nd ed.). Cambridge, UK: Cambridge University Press.

Mills, T. C., \& Markellos, R. N. (2008). The econometric modelling of financial time serie (3rd ed.). Cambridge, UK: Cambridge University Press.

Newey, W., \& West, W. (1987). A simple positive semi-definite, heteroskedasticity and autocorrelation consistent covariance matrix. Econometrica, 55, 703-708. http://dx.doi.org/10.2307/1913610

Phillips, P. C. B., \& Ouliaris, S. (1990). Asymptotic properties of residual based tests for cointegration. Econometrica, 58, 165-193. http://dx.doi.org/10.2307/2938339

Reiswich, D., \& Wystup, U. (2010). FX volatility smile construction. CPQF working paper No 20, Frankfurt School of Finance and Management.

Schwert, G. (1987). Effects of model specification on tests for unit roots in macroeconomic data. Journal of Monetary Economics, 20, 73-105. http://dx.doi.org/10.1016/0304-3932(87)90059-6

Shahbandarzadeh, H., Salimifard, K., \& Moghdani, R. (2013). Application of Monte Carlo simulation in the assessment of European call options. Iranian Journal of Management Studies, 6, 9-27.

Shastri, K., \& Tandon, K. (1986). Valuation of foreign currency options: some empirical tests. Journal of Financial and Quantitative Analysis, 21, 145-160. http://dx.doi.org/10.2307/2330734

\section{Copyrights}

Copyright for this article is retained by the author(s), with first publication rights granted to the journal.

This is an open-access article distributed under the terms and conditions of the Creative Commons Attribution license (http://creativecommons.org/licenses/by/3.0/). 